$\mathrm{HW}-83668$

UC-41, Health and Safety (TID $-4500,37$ th Ed.)

\title{
A REVIEW OF RESEARCH ON PLUTONIUM RELEASES DURING OVERHEATING AND FIRES
}

\author{
By \\ J. Mishima \\ Chemical Effluents Technolog fiRST UNRESTRICTED \\ Chemical Laboratory \\ Hanford Laboratories \\ DISTRIBUIIUN MADE \\ MAR 16 '65 \\ August 1964

\begin{abstract}
HANFORD ATOMIC PRODUCTS OPERATION
RICHLAND, WASHINGTON
\end{abstract}

Work performed under Contract No. AT (45-1)-1350 between the Atomic Energy Commission and General Electric Company

Printed by/for the U.S. Atomic Energy Commission

Printed in USA. Price \$2.00. Available from the Clearinghouse for Federal Scientific and Technical Information, National Bureau of Standards, U.S. Department of Commerce, Springfield, Virginia 


\section{DISCLAIMER}

This report was prepared as an account of work sponsored by an agency of the United States Government. Neither the United States Government nor any agency Thereof, nor any of their employees, makes any warranty, express or implied, or assumes any legal liability or responsibility for the accuracy, completeness, or usefulness of any information, apparatus, product, or process disclosed, or represents that its use would not infringe privately owned rights. Reference herein to any specific commercial product, process, or service by trade name, trademark, manufacturer, or otherwise does not necessarily constitute or imply its endorsement, recommendation, or favoring by the United States Government or any agency thereof. The views and opinions of authors expressed herein do not necessarily state or reflect those of the United States Government or any agency thereof. 


\section{DISCLAIMER}

Portions of this document may be illegible in electronic image products. Images are produced from the best available original document. 



\title{
A REVIEW OF RESEARCH ON PLUTONIUM RELEASES DURING OVERHEATING AND FIRES
}

\begin{abstract}
Articles and documents are reviewed which are concerned with oxidation and ignition temperatures of metallic and delta-phase stabilized plutonium, particle size distribution of oxide produced by heating plutonium and some of its compounds, deposition from turbulent streams, resuspension of plutonium dioxide particulate material from various surfaces, or release of plutonium during experimental and accidental fires.

In most instances, plutonium oxidation rates are found to increase with increasing temperature and humidity. A minimum rate is found in the delta-phase region due to changes in the oxide layer. Ignition can occur at temperatures above $100 \mathrm{C}$ depending upon the conditions of the metal and heating. The rate of release of plutonium dioxide aerosol increases with increasing temperature and gas velocity. Conditions in and around fires are variable and forces affecting the deposition of particles, complex. Once deposited in the soil, particulate material shows little tendency to resuspend. Several plutonium resuspension factors embracing many types of circumstances are listed.
\end{abstract}




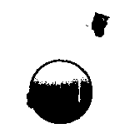

; 
TABLE OF CONTENTS

INTRODUCTION. BIOLOGICAL HAZARDS . OXIDATION RATES AND IGNITION TEMPERATURE $\quad$ • • • • • 2

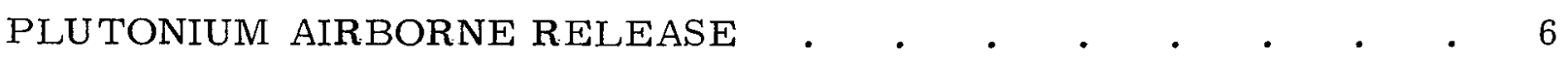
DEPOSITION $\quad$ • RESUSPENSION • CONCLUSIONS

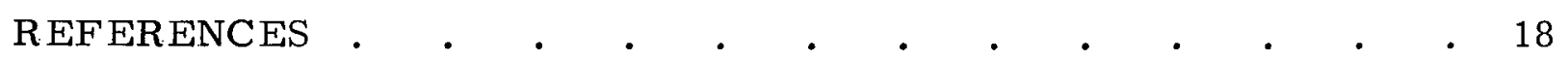
DISTRIBUTION • 


\section{A REVIEW OF RESEARCH ON PLUTONIUM RELEASES DURING OVERHEATING AND FIRES}

\section{INTRODUCTION}

This report is a review of the literature on plutonium release due to fires or overheating. The review was undertaken to consolidate the research results available and to disclose those areas where research is needed.

The relevance of such a review becomes apparent when one considers that the world's supply of plutonium will soon be measured in tons, (1) and that many facilities will be storing and fabricating plutonium fuels. This increased usage and handling will increase the possibility of plutonium release with subsequent inhalation exposure hazards.

The information collected is concerned with the fractional release from different sources under varying conditions, deposition, and resuspension. Also, the physical and chemical properties of the released radioactive materials must be known if the potential exposure hazard is to be assessed.

\section{BIOLOGICAL HAZARDS}

Plutonium-239 is one of man's most toxic substances. The International Commission on Radiological Protection (ICRP) recommends a maximum permissible body burden of $0.04 \mu \mathrm{Ci}^{*}$ or $0.6 \mathrm{\mu g}$, and maximum permissible concentrations in water and air for the general population of $1.7 \times 10^{-6}$ and $2 \times 10^{-14} \mu \mathrm{Ci} / \mathrm{cm}^{3}$, respectively. The se values are taken to be $1 / 30$ of the "continuous" occupational recommended maximum permissible concentration. (2)

The primary route of plutonium deposition in man is via inhalation. Except in a few situations in which large masses of the metal are handled, the exposure to external radiations from plutonium is small. Uptake in man following ingestion of plutonium is relatively low. Experimental data from animal exposures under a variety of conditions indicate that 0.002 to

* The abbreviation $\mu \mathrm{Ci}$ will be used for microcurie in this report, as recommended by the International Union of Pure and Applied Physics. 
to $0.007 \%(3,4)$ is taken up in the gastro-intestinal tract. Additionally, plutonium does not exhibit any tendency towards concentration at any stage of man's food cycle. Field and laboratory studies ${ }^{(5)}$ have shown that the ratio of plant to soil concentration ranges from about $10^{-4}$ to $10^{-3}$. Plutonium dioxide, the most likely compound present in accidental releases, is difficult to dissolve under laboratory conditions and may be solubilized only to a slight degree in body fluids. There is evidence, however, that fine particles are transferred through the alveclar membrane.

The ICRP formula for the reterition of particulate material in the lungs assumes that $12.5 \%$ of ail insoluble materials taken into the lungs is retained and taken up in the body fluids with a half-life of 120 days. Langham's modification assumes $10 \%$ will be sclubilized and taken into the body fluids. ${ }^{(7)}$ By either stardard, the principal mode of uptake by man is inhalation of finely divided particulate matter.

\section{OXIDATION RATES AND IGNITION TEMIPERATURE}

Both volatilization and release of particulate material may contribute to the total airborne concentration of pilutcnium. Hilliard, in a short review of the data available in 1961, concluded that true volatilization of plutonium or its dioxide is likely not a significant factor in the airborne hazard. The amount of particulate material suspended in air as a result of the oxidation of plutonium depends on many factors--the amourt and particle size distribution of the oxide produced, the deposition of particles along the path to the point of interest, and any resuspension of the deposited material.

The amount and particle size distribution of the oxide depend upon the amount and the physical division of the starting material and prior treatment. The oxide produced from a well dried oxalate heated slowly to 300 to $600 \mathrm{C}$ was in the 2 to $7 \mu$ size range, ${ }^{(9)}$ Continuously precipitated oxalate that was calcined at temperatures from 420 to $720 \mathrm{C}$ produced plutonium dioxide with median mass diameters from 5.2 to $12.0 \mu .^{(10-12)}$ Oxide produced by French experimenters ${ }^{(13)}$ from oxalate for use in reactor fuel preparation was $0.4 \%$ less than 325 mesh $(\sim 44$ w) when calcined at $550 \mathrm{C}$. Oxides produced by calcination of fluorides at $550 \mathrm{C}$ were $2.1 \%$ less than 325 mesh, but virtually no particies were less than $44 \mu$ when fluorides were calcined at 700 to $800 \mathrm{C}^{(14)}$ 
The oxidation of metallic plutonium has been pictured as a rapid initial attack of the effective surface area producing an adherent, protective layer of cubic and hexagonal $\mathrm{Pu}_{2} \mathrm{O}_{3} \cdot{ }^{(15)}$ This protective layer has been reported to range from $\sim 3 \mu(16)$ to $50 \mu^{(17)}$ in depth from room temperature through the gamma phase region in air and oxygen. Once formed, the protective layer limits oxidation and oxidation rates are linear (diffusion controlled) unless the protective layer is disturbed.

The oxidation rate of plutonium increases with increasing temperature until the delta phase region $(315$ to $452 \mathrm{C}$ ) is reached. At room temperature Waber ${ }^{(18)}$ reports only $0.96 \mathrm{mg} / \mathrm{cm}^{2}$ weight gain in $900 \mathrm{hr}$ in dry air. Stewart ${ }^{(16)}$ reports little change in specimens after $1 \mathrm{wk}$ in dry air. At $100 \mathrm{C}$ in dry air, Sackman ${ }^{(19)}$ observed the oxidation follows a succession of parabolic curves. Dempsey and Kay ${ }^{(20)}$ reported two-stage linear oxidation at $205 \mathrm{C}$, linear oxidation at $303 \mathrm{C}$, parabolic at $416 \mathrm{C}$, and initially parabolic accelerating to ignition at $487 \mathrm{C}$. A minimum oxidation rate has been reported by Notley et $\underline{\text { al }}{ }^{(15)}$ in the delta phase region and was attributed to an increased thickness in the adherent layers.

Recently, Schnizlein and Fisher ${ }^{(21)}$ in their oxidation studies using air and oxygen proposed a two-step oxidation mechanism from 120 to $560 \mathrm{C}$. The initial parabolic curve in the low temperature region is shown to have an activation energy of $32 \mathrm{kcal} / \mathrm{mole}$ and the subsequent linear curve an activation energy of $16 \mathrm{kcal} / \mathrm{mole}$. Values of 32 and $20 \mathrm{kcal} / \mathrm{mole}$ are assigned to the parabolic and linear rates above $420 \mathrm{C} .^{(17)}$

The acceleration of plutonium oxidation by moisture has been recognized since early studies at Los Alamos. (22) Dempsey and Kay ${ }^{(20)}$ showed the strong dependence of room temperature oxidation on moisture. Waber ${ }^{(18)}$ reported a $65 \%$ increase in oxidation rates from dry air to $50 \%$ relative humidity. Sackman ${ }^{(19)}$ found moisture can cause the breakup of the oxide layer before completion of oxidation, indicating trans- or intergranular corrosion. In his most recent report with Raynor, ${ }^{(23)}$ Sackman finds higher corrosion rates in humid atmospheres in the absence of oxygen, which, if present, would tend to seal the oxide layer from further corrosion 
by moisture. Stewart ${ }^{(16)}$ reports a visible increase of oxidation at $100 \%$ relative humidity. Schnizlein and Fisher ${ }^{(24)}$ indicate an oxidation rate increase by a factor of 6 when the moisture content is raised from $<5$ to $510 \mathrm{ppm}$ at $190 \mathrm{C}$ in oxygen. No difference in rates was observed in oxygen and air at $240 \mathrm{C}$ under the same moisture conditions. This agrees well with the findings of Dempsey and $\mathrm{Kay}^{(20)}$ at $55 \%$ relative humidity in air at $205 \mathrm{C}$, and indicates moisture loses its effect around the beta-gamma transition temperature $(210 \mathrm{C})$.

The change in oxidation rate with crystalline phase of plutonium is significant. Oxidation rates increase with increasing temperature until a maximum is reached near $416 \mathrm{C} .^{(15)}$ Notley et al. attribute the lowering of oxidation rates in the delta phase region to a balance between the increased thickness of the protective $\mathrm{Pu}_{2} \mathrm{O}_{3}$ layer and the decreased oxygen diffusion. Stewart ${ }^{(16)}$ proposes the similarity of crystalline forms of the delta phase metal and the dioxide provides a more adherent and partially crystalline oxide layer. Schnizlein and Fisher ${ }^{(17)}$ attribute the lowering of rates in this region to changes in oxide properties in this region. Waber; ${ }^{(18)}$ Waber, Olsen, and Roof; ${ }^{(25)}$ Sackman; ${ }^{(19)}$ Notley, Hodkins, and Davison; ${ }^{(15)}$ Carter, Foy, and Stewart; ${ }^{(26)}$ Stewart; ${ }^{(16)}$ and Schnizlein and Fisher ${ }^{(24)}$ have all reported decreases in oxidation rates in orders of magnitude by the addition of various metals stabilizing the delta phase of plutonium. Stewart ${ }^{(16)}$ and Schnizlein and Fisher $(24,27,28)$ have also reported increases in the ignition temperature of various plutonium delta phase binary alloys. Sackman ${ }^{(29)}$ assigns an activation energy of $21 \mathrm{kcal} / \mathrm{mole}$ to the linear oxidation of the delta alloy at $95 \%$ relative humidity in air.

As metallic plutonium or its alloys are heated, the material can ignite. If the reaction is self-sustaining, the entire bulk of the material will oxidize and considerably more material becomes available for suspension. Frank-Kamenetskii ${ }^{(30)}$ suggests that the ignition temperature is the gas temperature at which the heat generated by the reaction exceeds the heat transfer capacity of the protective oxide film. At this point, the 
temperature at the point of reaction (and throughout the metal with a material of the thermal conductivity of plutonium) builds up rapidly. The reaction rate is quickly transported to a higher regime until the reaction rate is limited and the heat transfer characteristics exceed the heat generated. At this time the temperature returns to near the original point and the cycle is repeated. Hilliard ${ }^{(31)}$ and Wanklyn ${ }^{(32)}$ have reported that uranium exhibits this type of ignition behavior. Schnizlein and Fisher ${ }^{(17)}$ have reported similar curves for plutonium. Ignition temperatures have been reported ranging from $110 \mathrm{C}^{(16)}$ for a delta phase swarf in air with an area/weight ratio of $13.3 \mathrm{~cm}^{2} / \mathrm{g}$ to $820 \mathrm{C}^{(21)}$ for a $30 \%$ plutonium, $6 \%$ zirconium, $64 \%$ uranium tertiary alloy in oxygen.

As has already been noted, plutonium oxidizes exothermally the reaction between plutonium and oxygen has a heat of reaction of $4.2 \mathrm{Btu} / \mathrm{g}$ plutonium). The amount of heat generated is a function of the area available for oxidation, the rate at which oxygen diffuses to the oxide-metal boundary, the thermal conductivity of the oxide layer, and the heat capacity of the system; because of this, both the gas temperature surrounding the specimen and the area/weight ratio of the specimen influence ignition. Schnizlein and Fisher ${ }^{(17)}$ have divided ignition behavior into two regimes. Metallic pieces with an area/weight ratio of $>5 \mathrm{~cm}^{2} / \mathrm{g}$ ignite at approximately $300 \mathrm{C}$. Ignition temperatures of approximately $500 \mathrm{C}$ are found for specimens with an area/weight ratio of $<1 \mathrm{~cm}^{2} / \mathrm{g}$. Discrepancies in ignition behavior of foils with area/weight ratios of $5.3 \mathrm{~cm}^{2} / \mathrm{g}$ are attributed to impurities or delta phase stabilization during heat treatment. Other deviations are cited in later experiments but were not explained. Local experience has shown that ignition of $2 \mathrm{~kg}$ buttons can occur at approximately $300 \mathrm{C}$. Stewart ${ }^{(16)}$ also reports ignition of a metal rod with an area/weight ratio of $0.31 \mathrm{~cm}^{2} / \mathrm{g}$ at $350 \mathrm{C}$ and a delta phase alloy with an area/weight ratio of $0.84 \mathrm{~cm}^{2} / \mathrm{g}$ at $340 \mathrm{C}$. Therefore, it appears temperature and area/weight ratios alone do not unequivocally define ignition temperatures.

Thus, the gas temperature at which the reaction rate jumps from a lower to a higher regime depends upon the equilibrium between heat generated (internal and external) and heat dissipated. If the heat can be 
removed at a sufficient rate, ignition does not occur. It is the experience in production areas where scraps of metallic plutonium are intentionally ignited prior to storage that, even after ignition has taken place, the reaction can be terminated if the oxidizing piece is brought into contact with an object, such as a metal spatula that can conduct away the heat. If the reaction rate is limited by an adherent rate-controlling film beneath the thermal conductivity capacity of the oxide film, ignition does not occur. This type of mechanism explains the ability of some metal specimens to oxidize completely without ignition in one set of conditions and ignite under others.

It could also explain the similarity in oxidation rates in air and oxygen reported by Schnizlein and Fisher ${ }^{(24)}$ and the dissimilar results reported by Carter, Foy, and Stewart. (26)

PLUTONIUM AIRBORNE RELEASE

The only article to date that comprehensively discusses plutonium aerosol release is K. Stewart's chapter in Vol. 5 of "Progress in Nuclear Energy, "Series IV. (16) In this chapter he covers plutonium oxidation rates, particle size distribution, and release rates in roughly four temperature categories.

Stewart finds the particle size distribution of the plutonium dioxide produced depends on the temperature of oxidation, the crystalline form of the metal and the humidity in the atmosphere. At room temperature in dry air, the pure metal yields particles with a median mass diameter (MMD) of 0.5 to $2 \mu$. As the temperature and moisture content increase, the particles produced become coarser and, due to the increased oxidation rate, the release rate increases. The delta alloys produce material with a particle size distribution similar to that of the pure metal at room temperatures, but due to the lower oxidation rate, its release rate is an order of magnitude lower. The rate of release of the pure metal at room temperature ranges from $1.5 \times 10^{-7} \mu \mathrm{Ci} / \mathrm{cm}^{2}-\mathrm{hr}$ in dry air to $5 \times 10^{-3} \mu \mathrm{Ci} /$ $\mathrm{cm}^{2}$-hr at $100 \%$ relative humidity. The delta alloys over the same range have rates from $5 \times 10^{-9} \mu \mathrm{Ci} / \mathrm{cm}^{2}-\mathrm{hr}$ to $4.5 \times 10^{-4} \mu \mathrm{Ci} / \mathrm{cm}^{2}-\mathrm{hr}$.

At temperatures above the alpha-beta transformation, the behavior of the metal and delta alloy are significantly different. In this temperature 
range, the release of oxide from pure metal to the air was small and continuous. The particle size distribution of the oxide produced was similar to that found at room temperature. The rate of release varied from $9 \times 10^{-4}$ to about $6 \times 10^{-3} \mu \mathrm{Ci} / \mathrm{cm}^{2}-\mathrm{hr}$, and was independent of temperature and humidity. It was noted that the oxide produced was friable and readily fragmented into particles $<3 \mu$ in diameter.

The material released from oxidation of the delta stabilized alloy was coarser having a MMD of $10 \mu$. The release of oxide was sporadic and corresponded to the stepwise oxidation of this material indicative of the successive cracking of the oxide layer. The rate of release ranged from $1 \times 10^{-2} \mu \mathrm{Ci} / \mathrm{cm}^{2}-\mathrm{hr}$ (an order of magnitude greater than the pure metal) to $9 \times 10^{-5} \mu \mathrm{Ci} / \mathrm{cm}^{2}-\mathrm{hr}$ (an order of magnitude lower than the pure metal) with increasing humidity.

Above the beta-gamma phase transformation, the particles produced are hard and amorphous with a MMD of 350 to $1000 \mu$. Although the amount of oxide produced increases greatly, the percentage of oxide in the respirable size range is much lower than that produced at lower temperatures.

Stewart detected the existence of two groups of particles based on their geometric standard deviations $(\sigma)$ which Kottler has shown to be related to the rate constant of the formation processes in a log-normal distribution. The basic particles separated from the basic mass due to internal stress had a $\sigma$ in the region of 2 to 4 while particles formed during breakaway by attrition, etc., had a $\sigma$ of 10 to 15 .

The particle size distribution of the oxide formed from the pure metal and delta alloy in the four temperature ranges mentioned fell into four approximate size distributions. The effects of gas velocity upon release rates were divided into two groups: "static", which involves no physical disturbance and a velocity of $<1 \mathrm{~m} / \mathrm{sec}$; and "dynamic", which assumes complete dispersal of all oxide produced. Stewart correlated the particle size distribution and release rate found for the metal and delta alloy under the stated conditions of temperature and gas velocities 
with a lung retention model, and arrived at an "effective source strength." The downwind inhalation hazard from any of the stated conditions can then be calculated by use of one of the existing transport formulae. To calculate the potential lung deposition in an individual exposed to the aerosol throughout the time of emission. Stewart uses the formula:

$$
\text { Dose }(\mu \mathrm{C} i):=(\mathrm{ESS})(\mathrm{A})(\mathrm{R})[\mathrm{f}(\mathrm{W})]
$$

where (ESS) is the effective source strength. A is the area of the metal oxidized, $R$ is the breathing rate and $f(W)$ is the aerosol dispersion function according to Sutton or Pasquill.

British workers have conducted a large scale, outdoor experiment to determine plutonium dispersion during a fire. (33) In these tests, 200-g rods of plutonium were suspended in a $4 \mathrm{ft}$ square chimney, $11 \mathrm{ft}$ high. The rods were heated by a gasoline fire at $850 \mathrm{C}$ for $30 \mathrm{~min}$ and by slow, programmed increases to $600 \mathrm{C}$ in $1 \mathrm{hr}$. The $\mathrm{PuO}_{2}$ release was measured by weight loss, integration of the deposition curve and integration of the downwind air concentration. Weight loss gave the highest release rate but difficulties in full recovery of the residue casts doubts on the validity of the results. All release rates obtained from the lower temperature oxidation were higher. In reporting the data Stewart concludes that:

- No significant inhalation hazard would exist at greater than 200 yards from burning several kilograms of plutonium.

- A release value of $0.05 \%$ is a satisfactory, safe value for estimating the airborne hazard downwind.

Other corroborative information is obtained from accident reports involving plutonium. A recent incident at Hanford ${ }^{(34)}$ involved a fire in a plutonium purification area. Some explosive mechanism ruptured an ion exchange column and ignited other materials in the vicinity. The building filters remained intact and only $225 \mu \mathrm{Ci}$ were released via the stack。 Although smoke was observed leaking from the stairwell structure and one door was blown open, no significant contamination was detected on the ground beyond 20 yards. The presence of large amounts of carbon and organic vapors 
in the smoke may have played a significant role in limiting the spread of contamination and increasing the deposition of airborne plutonium dioxide particles. Air monitors at the perimeter of the area recorded only slightly higher than detectable levels.

Earlier incidents occurring at Oak Ridge National Laboratory and Rocky Flats Plant ${ }^{(35)}$ also indicated low airborne release of plutonium from fires and explosion even with loss of building filters. Table I summarizes the data found in literature on the behavior of plutonium at various temperatures.

\section{DEPOSITION}

Very little has been written on the deposition of plutonium or its oxide. Stewart ${ }^{(16)}$ lists deposition velocities* of $7.3 \mathrm{~cm} / \mathrm{sec}$ for a size distribution with a MMD of $0.3 \mu$, to $3.2 \mathrm{~cm} / \mathrm{sec}$ for a size distribution with MMD of 16 and $29 \mu$ for the particles airborne at or above the ignition temperature. The unusually high deposition velocity noted for the $0.3 \mu$ particles is for the material dispersed into the glove box from the violent reaction between oxygen and a thin metallic disk and is likely not representative of normally formed particles of this size. Cheevers ${ }^{(37)}$ in his exploding wire experiments on plutonium has reported only $0.00055 \%$ of the resultant oxide reaches the filter at a gas velocity of $5 \mathrm{fpm}$. In outdoor tests with large plutonium rods at 600 to $800 \mathrm{C}$, most of the airborne particles settled out within 200 yards of the release point. (38)

The deposition of particles during a fire is a complex process. The thermal updrafts created by the heat would counteract the gravitational effects near the fire. Diffusion due to temperature and concentration gradients cause some deposition of submicron particles near the source while turbulent deposition and impaction would also take place. These latter effects are especially important for particles larger than about 2 to $5 \mu$.

Away from the source of heat, particles will be carried and dispersed with the air currents and deposit due to settling, impingement, and turbulent impaction with objects. Friedlander and Johnstone ${ }^{(38)}$ hypothesize

* The deposition velocity is defined ${ }^{(36)}$ as the number of particles deposited per $\mathrm{cm}^{2} / \mathrm{sec}$ divided by the number of particles per $\mathrm{cm}^{3}$ in the gas above the surface. 
SUMM ARY OF OBSERVATIONS OF PLUTONIUM BEHAVIOR

\section{AT VARIOUS TEMPERATURES}

Temperature

To $120 \mathrm{C}$

(Pure metal in a phase)

120 to $210 \mathrm{C}$

(Pure metal in $\beta$ phase)

210 to $315 \mathrm{C}$

(Pure metal in $\gamma$ phase)

315 to $452 \mathrm{C}$ (Pure metal in 8 phase)

At Ignition

$\frac{\text { Property, Behavior }}{\text { Oxidation Rate }\left(\mathrm{mg} \mathrm{PuO}_{2} / \mathrm{cm}^{2}-\mathrm{hr} \text { ) }\right.}$

$$
\text { Particle Sizes }
$$

Release Rate ( $\mu \mathrm{Ci} / \mathrm{cm}^{2}-\mathrm{hr}$ )

(at about 14 to $24 \mathrm{~cm} / \mathrm{sec}$ )

Dry Air

$100 \%$ Relative Humidity Air

Range of Release Rate as a

Function of Velocity over

Specimen:
Low Flow: $<1 \mathrm{~m} / \mathrm{sec}$
High Flow: Sufficient to make airborne all oxide particles

Oxidation Rate $\left(\mathrm{mg} \mathrm{PuO}_{2} / \mathrm{cm}^{2}-\mathrm{hr}\right.$ )

Particle Sizes

Release Rate $\left(\mu \mathrm{Ci} / \mathrm{cm}^{2}-\mathrm{hr}\right)$

(in ambient air)

Range of Release Rate as a

Function of Velocity over

Specimen:

Low Flow: $<1 \mathrm{~m} / \mathrm{sec}$

High Flow: Sufficient to make airborne all oxide particles

Oxidation Rate ( $\mathrm{mg} \mathrm{PuO}_{2} / \mathrm{cm}^{2}-\mathrm{hr}$ )

Particle Sizes

Release Rate

Range of Release Rate, etc.

Oxidation Rate $\left(\mathrm{mg} \mathrm{PuO}_{2} / \mathrm{cm}^{2}-\mathrm{hr}\right.$ )

\section{Particle Sizes}

Release Rate

(effect of humidity)

Range of Release Rate as a

Function of Velocity over

Specimen:

Low Flow: $<1 \mathrm{~m} / \mathrm{sec}$

High Flow: Sufficient to make airborne all oxide particles

Oxidation Rate ( $\mathrm{mg} \mathrm{PuO}_{2} / \mathrm{cm}^{2}-\mathrm{hr}$ )

Particle Sizes

Integrated Release for $100 \%$ Conversion to Oxide

Values
for Relatively Pure Metal
0.009 to 10

$85 \%<6 \mu$

$\sim 1.5 \times 10^{-7}$

Low: 0.0005

$$
\text { to }
$$

High: 5

0.2 to 9

$85 \%<6 \mu$

0.005

Low: 0.005

to

High: 5000

4.5 to ignition $\dagger$

Not available

Not available

Not available

11 to ignition $\$$

$85 \%<6 \mu$ to $3 \%<6 \mu$

Difference in rates not measurable

Low: 0.0005

High: 50

Not available

Not available

Not available
Values

for Stabilized 5 Phase (Binary)

Not detectable to ignition*

$85 \%<6 \mu$

$\sim 5 \times 10^{-9}$

$\sim 5 \times 10^{-5}$

Low: $5 \times 10^{-5}$

High: 0.5

0.5 to ignition ${ }^{* 2}$

$85 \%<6 \mu$ to $5 \%<6 \mu$

0.0005
0.35 to ignitiontt

4 to ignition $\$ \$$

$85 \%<6 \mu$ to $3 \%<6 \mu$

Low: 10 to

High: 40,000

Low: 10 to

High: 40,000

Highly variable

Highly variable

MMD 350 to $1000 \mu$

$\sim 0.2 \%<6 \mu$

MMD 350 to $1000 \mu$ $\sim 0.2 \%<6 \mu$

$0.02 \%$ to $100 \%$

$0.02 \%$ to $100 \%$

(Highly variable, depending upon mass and geometry of specimen)

** $\delta$ metal turnings: area $/$ weight $=8.7$ to $13.8 \mathrm{~cm}^{2} / \mathrm{g}$

计 $\delta$ metal rod: area/weight $=1.4 \mathrm{~cm}^{2} / \mathrm{g}$
* $\delta$ metal turnings: area $/$ weight $=13.3 \mathrm{~cm}^{2} / \mathrm{g}$

$+2 \mathrm{~kg}$ metal buttons

$\$$ Metal rod: area/weight $=0.31 \mathrm{~cm}^{2} / \mathrm{g}$ 
that particles in a turbulent stream are projected through the last portion of the boundary layer near a surface by the transverse eddy velocities in the turbulent layer. The thickness of the boundary layer is related to the stopping distance, $\mathrm{S}$, of the particle. Mass transfer rates can be deduced with the assumption that particles need to diffuse to within one stopping distance of the surface. For particles in the 1 to $10 \mu$ size range and at low gas velocities, deposition varies with the square of the terminal velocity.

Chamberlain ${ }^{(39)}$ found that a roughness element extending 10 to $100 \mu$ into the laminar sublayer may be significant in the deposition of small particles. In his work with dry deposition on grass, he deduces a minimum in deposition velocities for particles with a diameter of $0.1 \mu$. He proposes that for particles of high density and $>10 \mu$ in diameter, the deposition velocity is equal to the terminal velocity. For submicron particles, deposition velocities near 0.1 to $0.3 \mathrm{~cm} / \mathrm{sec}$ are indicated.

Tanner ${ }^{(40)}$ has calculated the disproportionate disappearance of particles from an aerosol containing a spectrum of particle sizes due to gravitational settling. For a turbulent aerosol (one having random eddies of velocities less than 1 mile/h) at room temperature, the ratio of the number remaining suspended to the initial number is:

$$
-\ln \left(\frac{n_{t}}{n_{o}}\right)=\frac{\left(\rho_{p}-\rho_{g}\right) g d^{2} C t}{18 \eta h}
$$

where $n_{t}=$ number of particles at time $t$

$\mathrm{n}_{\mathrm{O}}=$ number of particles at time zero

$p_{p}=$ density of particles $\left(\mathrm{g} / \mathrm{cm}^{3}\right)$

$\rho_{\mathrm{g}}=$ density of gas $\left(\mathrm{g} / \mathrm{cm}^{3}\right)$

$\mathrm{g}=$ acceleration due to gravity $\left(\mathrm{cm} / \mathrm{sec}^{2}\right)$

$\mathrm{d}=$ diameter of particle $(\mathrm{cm})$

$\mathrm{t}=$ time (sec)

$\eta=$ viscosity of gas (poise, $\mathrm{g} / \mathrm{sec}-\mathrm{cm}$ )

$\mathrm{h}=$ height of chamber $(\mathrm{cm})$

$\mathrm{C}=$ Cunningham's correction factor (dimensionless). 
Table II shows the fraction of various size $\mathrm{PuO}_{2}$ spherical particles (density 11.46) remaining airborne in a $10 \mathrm{ft}$ high chamber after release. Under these conditions greater than $99.9 \%$ of all particles aerodynamically equivalent to a sphere of $\mathrm{PuO}_{2}$ larger than $10 \mu$ would have settled out within $10 \mathrm{~min}$. Within approximately $1 \mathrm{hr}$, greater than $99.9 \%$ of all particles larger than $4 \mathrm{\mu}$ would have settled out. More than $10 \mathrm{hr}$ would be required to reduce the airborne concentration of $1 \mu$ particles to this level.

TABLE II

\section{GRAVITATIONAL SETTLING OF PARTICLES}

\begin{tabular}{|c|c|c|c|c|c|c|c|c|c|c|c|c|c|}
\hline $\begin{array}{l}\text { Diam., } \mathrm{N} \\
r_{\mathrm{l} / \mathrm{n}_{\mathrm{o}}}\end{array}$ & 1 & 2 & 3 & 4 & 5 & 6 & 7 & 8 & 9 & 10 & 12 & 15 & 20 \\
\hline 0.0 & 13.7 & 3.7 & 1.7 & 0.95 & 0.62 & 0.43 & 0.32 & 0.24 & 0.19 & 0.16 & 0.11 & 0.07 & 0.04 \\
\hline 0.8 & 29.1 & 7.8 & 3.56 & 2.03 & 1.31 & 0.92 & 0.68 & 0.52 & 0.42 & 0.33 & 0.23 & 0.15 & 0.08 \\
\hline 0.7 & 46.5 & 12.5 & 5.69 & 3.24 & 2.10 & 1.46 & 1.08 & 0.83 & 0.65 & 0.53 & 0.37 & 0.24 & 0.13 \\
\hline 0.6 & 66.6 & 17.9 & 8.16 & 4.65 & 2.98 & 2.10 & 1.54 & 1.17 & 0.94 & 0.76 & 0.53 & 0.34 & 0.19 \\
\hline 0.5 & 90.3 & 24.3 & 11.1 & 6.30 & 4.07 & 2.82 & 2.10 & 1.61 & 1.27 & 1.03 & 0.72 & 0.46 & 0.26 \\
\hline 0.4 & 119.4 & 32.1 & 14.6 & 8.32 & 5.37 & 3.75 & 2.77 & 2.13 & 1.68 & 1.37 & 0.95 & 0.61 & 0.37 \\
\hline 0.368 & 130.3 & 35.1 & 16.0 & 9.09 & 5.85 & 4.09 & 3.00 & 2.32 & 1.84 & 1.49 & 1.04 & 0.66 & 0,34 \\
\hline 0.3 & 156.9 & 42.2 & 19.2 & 11.0 & 7.07 & 4.92 & 2.77 & 2.79 & 2.21 & 1.79 & 1.25 & 0.80 & 0.45 \\
\hline 0.2 & 209.8 & 56.5 & 25.7 & 14.7 & 9.44 & 6.59 & 4.87 & 3.72 & 2.95 & 2.40 & 1.67 & 1.07 & 0.60 \\
\hline 0.1 & 300.1 & 80.8 & 36.8 & 21.0 & 13.5 & 9.44 & 6.97 & 5.34 & 4.23 & 3.43 & 2.39 & $1.53^{\circ}$ & 0.86 \\
\hline 0.01 & 600.3 & 161.6 & 73.6 & 41.9 & 27.0 & 18.9 & 13.9 & 10.7 & 8.46 & 6.86 & 4.76 & 3.06 & 1.73 \\
\hline 0.001 & 900.4 & 242.4 & 110.4 & 62.9 & 40.6 & 28.3 & 20.9 & 16.0 & 12.7 & 10.3 & 7.15 & 4.60 & 2.59 \\
\hline
\end{tabular}

Outdoors, many other factors such as meterological and geographical factors would influence transport and deposition. Stewart ${ }^{(41)}$ reports that half the fine airborne particulate material from Operation Plumbob settled out in approximately 37 days. This is indicative of the small size of the particles remaining airborne.

\section{$\underline{\text { RESUSPENSION }}$}

After the plutonium particulate material is deposited, the principal hazard is inhalation of resuspended material. The amount resuspended, under stated conditions, is generally given as a resuspension factor:

$$
K\left(\mathrm{~m}^{-1}\right)=\frac{\text { Airborne concentration (units } \left./ \mathrm{m}^{3}\right)}{\text { Surface contamination (units } / \mathrm{m}^{2} \text { ) }}
$$

Table III is a compilation of resuspension factors that have been reported in the literature. 
TABLE: III

RESUSPENSION FACTORS FOR AIRBORNE RADIOACTIVE AEROSOLS

Conditions of Resuspension

Average Resuspension Factor in Accidents Involving Plutonium

Vehicular Traffic (Nevada)

People Working or Active in a Closed Area

Dirty Rural, Suburban, or Metropolitan Areas

People Working or Active in an Open Area

Isolated Area

Resuspensian of Aged Plutonium Deposit $\left(0.74\right.$ to $\left.752 \mu \mathrm{Ci} / \mathrm{m}^{2}\right)$ from "Plumbob"

Plutonium Oxide, No Movement

Plutonium Oxide, 14 steps/min

Plutonium Oxide, 36 steps/min

Plutonium Nitrate, No Movement

Plutonium Nitrate, 14 steps/min

Plutonium Nitrate, 36 steps/min

Plutonium Oxide, Change Room $\left(>3000 \mathrm{ft}^{2}\right), 9$ air changes $/ \mathrm{hr}, 0.01 \mathrm{\mu Ci} / \mathrm{m}^{2}$ 4 to 6 persons active in area:

"Loose" Contamination (estimated by smears)

"Loose" Contamination (estimated by water-detergent wash)

Changing Coveralls, Static Sampler, No Ventilation

Changing Coveralls, Personal Sampler, No Ventilation

Personnel Traffic in a Small Unventilated Room

Proposed Resuspension Factors for Plutonium Oxide:

Outdoors (quiescent conditions)

Outdoors (moderate activity)

Indoors (quiescent conditions)

Indoors (moderate activity)

From Crater of Tower Shot, No Artificial Disturbance

Survey of Road, No Artificial Disturbance

Survey of Road, Landrover, D-Day +4

Survey of Road, Landrover, D-Day +7

Survey of Road, Tailboard of Landrover, D-Day +7

Survey of Road, D-Day +1 and 2

Sample Collection in Cab of Landrover, $\mathrm{H}-\mathrm{Hour}+5$

Sample Collection in Cab of Landrover, H-Hour +8

Uranium Sample Downwind of Crater, Sample Height: 1 ft Above Ground

Uranium Sample Downwind of Crater, Dust Stirred Up, Sample Height: $1 \mathrm{ft}$

Uranium Sample Downwind of Crater, Sample Height: $2 \mathrm{ft}$

Plutonium Sampled $1 \mathrm{ft}$ Above Ground:

Vehicular Dust

Pedestrian Dust

Iodine-131, Enclosed (Chamberlain \& Stanbury)

Iodine-131, Open (Chamberlain \& Stanbury)

Yttrium-91, 0-8 $\mu$ Particles, Natural Turbulence, Sampled 1 ft Above Ground: Ground Contamination Level $1.8 \mu \mathrm{Ci} / \mathrm{m}^{2}$ Ground Contamination Level $8.8 \mu \mathrm{Hi} / \mathrm{m}^{2}$ Ground Contamination Level $24.6 \mu \mathrm{Ci} / \mathrm{m}^{2}$

Polonium-210, 0-8 $\mu$ Particles, Natural Turbulence, Sampled $1 \mathrm{ft}$ Above Ground: Ground Contamination Level $0.6 \mu \mathrm{Ci} / \mathrm{m}^{2}$

$\mathrm{U}_{3} \mathrm{O}_{8}, 0-4 \mu$ Particles, Natural Turbulence, Sampled $1 \mathrm{ft}$ Above Ground:

Ground Contamination Level $112 \mathrm{~g} / \mathrm{m}^{2}$

Grass Contamination Level $70 \mathrm{~g} / \mathrm{m}^{2}$
Concrete Contamination Level $180 \mathrm{~g} / \mathrm{m}^{2}$

Plutonium Oxide, Sampling Height: $5 \mathrm{ft}$

Floor Level $0.1 \mu \mathrm{Ci} / \mathrm{m}^{2}$, No Circulation

Floor Level $24,6 \mu \mathrm{Ci} / \mathrm{m}^{2}$, No

Floor Level $0.1 \mu \mathrm{Ci} / \mathrm{m}^{2}$ Fan

Floor Level $0.91 \mathrm{\mu i} / \mathrm{m}^{2}{ }^{2}$ Fan

Floor Level $1.3 \mu \mathrm{Ci} / \mathrm{m}^{2}$, Fan and Dolly

Floor Level $1.3 \mu \mathrm{Ci} / \mathrm{m}^{2}$, After Test

Floor Leve1 1.1 $\mathrm{Ki} / \mathrm{m}^{2}$, After Test

Uranium, Sampling Height: $5 \mathrm{ft}$

Floor Level $0.086 \mu \mathrm{Ci} / \mathrm{m}^{2}$, No Circulation

Floor Level $0.95 \mu \mathrm{Ci} / \mathrm{m}^{2}$ "No Circulation

Floor Level $0.095 \mu \mathrm{Ci} / \mathrm{m}^{2}, \mathrm{Fan}$

Floor Level 1.1 $\mu \mathrm{Ci} / \mathrm{m}^{2}$ Fan

Floor Level $0.11 \mu \mathrm{Ci} / \mathrm{m}^{2}$, Doll

Floor Level $0.11 \mu \mathrm{Ci} / \mathrm{m}^{2}$, Dolly
Floor Level $1.3 \mu \mathrm{Ci} / \mathrm{m}^{2}$, Dolly

Floor Level $0.91 \mu \mathrm{Ci} / \mathrm{m}^{2}$, Fan and Dolly

Floor Level $1.0 \mu \mathrm{Ci} / \mathrm{m}^{2}$, Fan and Dolly

* One high value excluded

+ Only $\sim 20 \%$ of particles $<6 \mu$

$\$$ Particles primarily in 20 to $60 \mu$ size range, $<1 \%<6 \mu$
Resuspension Factor Reference

$4 \times 10^{-6} \mathrm{~m}^{-1}$

$7 \times 10^{-5}$

$4 \times 10^{-5}$

$4 \times 10^{-5}$
$7 \times 10^{-6}$

$2 \times 10^{-6}$

$6.2 \times 10^{-10}$

to $10^{-13}$

$2 \times 10^{-8}$

$10^{-5}$
$\times 10^{-5}$

$5 \times 10^{-5}$

$\times 10^{-8}$

$10^{-6}$

$5 \times 10^{-6}$

14

$2 \times 10^{-4}$

$2 \times 10^{-4}$
$2.8 \times 10^{-3}$

$6.4 \times 10^{-3}$

$4 \times 10^{-3}$

$10^{-6}$
$10^{-5}$
$10^{-6}$
$10^{-4}+10^{-5}$

$8 \times 10^{-8 * x}$

$8 \times 10^{-8 *}$

$1.4 \times 10^{-5}$

$1.5 \times 10^{-6}$

$2 \times 10^{-5}$

$4 \times 10^{-7}$

$6.4 \times 10^{-5}$ 汻米

$2.5 \times 10^{-5 \dagger}$

$3 \times 10^{-4}+4$

$10^{-3}+t$
$10^{-5}+t$

$5 \times 10^{-4 \$}$

$1.5 \times 10^{-6 \$}$

$2 \times 10^{-4}$ to

$4 \times 10^{-5}$
$2 \times 10^{-6}$

$1.8 \times 10^{-7}$

$10^{-8}$

$3 \times 10^{-10}$

$2 \times 10^{-6}$

$2.4 \times 10^{-6}$

$8 \times 10^{-6}$
$2 \times 10^{-6}$

1. $6 \times 10^{-6}$

$4.4 \times 10^{-7}$

1. $3 \times 10^{-3}$

$1.4 \times 10^{-3}$

1. $0 \times 10^{-2}$

$9.4 \times 10^{-3}$

$9 \times 10^{-4}$

1. $8 \times 10^{-6}$

$2.2 \times 10^{-7}$

$1.5 \times 10^{-4}$

1. $1 \times 10^{-4}$

1. $6 \times 10^{-4}$

1. $6 \times 10^{-4}$
$1.3 \times 10^{-4}$

$1.3 \times 10^{-4}$
$4.6 \times 10^{-4}$

1. $9 \times 10^{-4}$
47 
The various factors listed show considerable variations ranging from $1 \times 10^{-2^{(42)}}$ (resuspension of a finely divided material from a newly painted concrete floor due to air and mechanical motion) to $10^{-13} \mathrm{~m}^{-1}(5)$ (resuspension of aged plutonium particulate material from desert soil by natural turbulence).

Values ranging from $7 \times 10^{-7}$ to $7 \times 10^{-5} \mathrm{~m}^{-1}$ were calculated from data obtained during Operation Plumbob. (43) The U.S. Navy suggests a factor of $4 \times 10^{-6}$ for use in weapons accidents calculations, ${ }^{(44)}$ which agree agrees well with Stewart's ${ }^{(41)}$ proposed value of $1 \times 10^{-6} \mathrm{~m}^{-1}$ derived from resuspension data obtained from many sources. In his paper presented to the International Symposium on Surface Contamination, Stewart outlines some of the significant mechanisms and factors influencing resuspension of particulate material.

From available information, this author concludes that after particles are deposited on the ground, they tend to remain fixed in place due to mixing into the top layer of loose soil (the process of weathering). This is illustrated well by the data from Operation Plumbob trials ${ }^{(45)}$ which show that greater than $90 \%$ of the plutonium deposited remained fixed in the soil. Olafsen and Larson ${ }^{(5)}$ returning to the original Plumbob site found resuspension factors of $10^{-10}$ to $10^{-13} \mathrm{~m}^{-1}$ from this aged material.

The boundaries of the contaminated area tend to increase somewhat with time due to the wind erosion processes of saltation, suspension, and surface creep but losses from the area are small since only a small fraction is of the size range to become airborne. In the presence of greater turbulence, a larger proportion of small particles, or increased physical activity in the area, more material is resuspended.

In the event of an accidental release, plutonium dioxide deposited would tend to remain fixed. The amount resuspended would depend upon surface, turbulence, particle size distribution of the particulate material and activity within the area. In a controlled area, the resuspension factor would be in the range of $10^{-5}$ to $10^{-6} \mathrm{~m}^{-1}$ and the amount airborne would tend to depend upon the conditions and contamination level of the area upwind. 
Some extension of the contaminated area with time is to be expected. Resuspension rates will decrease with time due to "weathering" of the contamination and the depletion of fine material.

Corn's ${ }^{(48)}$ assertion that the most probable mechanism for redispersion of particles from a surface under normal conditions is a transfer of momentum from large moving objects appears to be borne out by the data presented to date. $(41-43,46,47)$

\section{CONCLUSIONS}

Since the conditions existing during any individual fire are almost unique for the circumstances existing at that moment in time, it is only possible to discuss plutonium aerosol release from fires in general terms.

Fires involving plutonium compounds in air generally result in the formation of plutonium dioxide. The particle size distribution and release rate of the dioxide would vary with prior treatment and fire conditions. If the material is a well-dried, free-flowing oxalate, the dioxide produced would be in the form of a finely divided particle, readily dispersed and primarily in the size range of greatest inhalation hazard. If the same material were in a wet cake or slurry and heated at a rapid rate, the amount released would be significantly reduced.

In fires involving metallic plutonium, physical shape, prior treatment, and fire conditions play significant roles. Generally below ignition, the greater the surface area, temperature, and gas velocities, the greater is the release. For instance, the "effective source strength" at 400 to $500 \mathrm{C}$ is $0.02 \mu \mathrm{Ci} / \mathrm{cm}^{2}$-min under static conditions and $2 \mu \mathrm{Ci} / \mathrm{cm}^{2}$ - $\mathrm{min}$ for dynamic conditions. (16) At temperatures above $100 \mathrm{C}$, the equilibrium between heat dissipated and heat input (internal and external) can result in the ignition of the plutonium. Above ignition, the amount of material released depends on the total weight of plutonium available and gas velocities. The "effective source strength". at and above ignition temperatures under static conditions is $2000 \mu \mathrm{Ci} / \mathrm{kg}$ and $10,000 \mu \mathrm{Ci} / \mathrm{kg}$ under dynamic conditions. (16) 
Airborne aerosols in nominal plutonium fires and routine operations are controlled by high efficiency filters at each work zone with back-up filters just prior to release. In serious fires and explosions in which these barriers may be by-passed and breached, it becomes necessary to use the data outlined above to predict the consequences of the incident. Additional research is indicated to better define deposition in ducts and on surfaces, and to establish realistic release factors for typical fires.

In the event of fires in the open, even if several kilograms of plutonium were in a fire, no significant inhalation hazard will likely exist beyond several hundred yards downwind. Once deposíted, plutonium dioxide tends to "weather into" the top layer of soil and become fixed at the location. Only large disturbances such as vehicular traffic, unrestricted movement of personnel, wind storms or displacement of the upper layers of soil would move the deposited material any significant distance.

In general, knowledge of the trends listed above is required in understanding the mechanisms involved in the formation and release of a plutor nium dioxide aerosol, the amount of material released in quiescent conditions, the amount potentially available to be released under these conditions and the behavior of the aerosol once it has been deposited. The information available is not sufficient to make a quantitative evaluation of the amount of plutonium dioxide released during any given fire situation.

No data are given on the increase or reduction of plutonium dioxide particulate material in the respirable range from variations in fire conditions. The effects of variations in gas velocity upon the particle size distribution and amount released, and the effects of other materials such as organics or alloying metals, upon the amount released are not available. Most experimenters have been concerned with metallic plutonium. Rags and paper wipes and other debris which have been used to absorb soluble plutonium salts may yield aerosols of unique properties, which should be identified。

The penetration of high efficiency filters by particles released in plutonium overheating incidents should be measured for some incidents to 
gain assurance that particles will be effectively retained. Although the filter media are very reliable, a demonstration of high efficiency for the airborne material in a plutonium incident would be of value.

Correlations between existing oxidation rate values and release rates could not be made due to the variations in experimental conditions. Since all the release values available are under one set of experimental conditions, additional data and corroboration of existing values is desirable。 


\section{REFERENCES}

1. N. G. Wittenbrock. The Plutonium Recycle Program at Hanford, HW-SA-3321. January 1964.

2. "Report of Committee II on Permissible Dose for Internal Radiation (1959), " Health Phys., vol. 3, pp. 1-380. June 1960.

3. M. H. Weeks, J. Katz, W. D. Oakley, J. E. Ballou, L. A. George, L. K. Bustad, R. C. Thompson, and H. A. Kornberg. "Further Studies on the Gastrointestinal Adsorption of Plutonium, "Radiation Res., vol.4, pp. 339-347. 1957.

4. K. G. Scott, D. J. Axelrod, H. Fisher, J. F. Crowley, and J. G. Hamilton. "The Metabolism of Plutonium in Rats Following Intramuscular Injection," J. Biol. Chem., vol. 176, pp. 233-293. 1948.

5. J. H. Olafson and K. H. Larson. Plutonium, Its Biology and Environmental Persistance, UCLA-501, University of California, Los Angeles. December 1961.

6. W. J. Bair and D. H. Willard. "Plutonium Inhalation Studies--III. Effects of Particle Size and Total Dose on Deposition, Retention and Translocation, "Health Phys., vol. 9, pp. 253-266. 1963.

7. W. H. Langham. "Determination of Internally Deposited Radioactive Isotopes from Excretion Analysis," Am. Ind. Hyg. Assoc. Quart., vol. 17, pp. 305-318. 1956.

8. R. K. Hilliard. Probable Volatilization of Plutonium During a Fire, $\mathrm{HW}-71743$. December 1, 1961.

9. M. N. Meyers. Thermal Decomposition of Plutonium (IV) Oxalate and Hydrofluorination of Plutonium (IV) Oxalate and Oxide, HW-45128. August 1, 1956.

10. Development of Plutonium Bearing Fuel Materials, Monthly Progress Letter for November, 1961, NUMEC-P36.

11. Development of Plutonium Bearing Fuel Materials, Progress Report for Period July 1 to September 30, 1961, NUMEC-P80.

12. Development of Plutonium Bearing Fuel Materials, Progress Report for January 1 to March 31, 1962, NUMEC-P100.

13. Use of Plutonium as a Fuel in Nuclear Reactors, Quarterly Report No. 5, July-September, 1961, USAEC Report EURAEC 176.

14. Study of the Sintering of $\mathrm{UO}_{2}-\mathrm{PuO}_{2}$ Mixtures--Special Report No. 4. 1 , USAEC Report EURAEC 282 .

15. M. J. F. Notley, E. N. Hodkin, and J. A. C. Davidson. The Oxidation of Plutonium and Certain Plutonium Alloys in Air and Carbon Dioxide, AERE-R/4070, AERE, Harwell, England, 1962. 
16. K. Stewart. "The Particulate Material Formed by the Oxidation of Plutonium, " Progress in Nuclear Energy, Pergamon Press, New York, 1963. Series IV, vol. 5.

17. J. G. Schnizlein and D. F. Fisher. "Isothermal Oxidation of Plutonium, "Chemical Engineering Division Summary Report, January, February, March 1963, p. 187, ANL-6687. Argonne National Laboratory.

18. J. T. Waber. "The Corrosion Behavior of Plutonium and Uranium," The Second International Conference on the Peaceful Uses of Atomic Energy, vol. 6, p. 204. 1958.

19. J. F. Sackman. "The Atmospheric Oxidation of Plutonium Metal," Plutonium 60 The Proceedings of the Second International Conference on Plutonium Metallurgy, Grenoble, France, 1960.

20. E. Dempsey and A. E. Kay. "Some Investigations on Plutonium Metal, "J. Inst. Metals, vol. 86, p. 379.

21. J. G. Schnizlein and D. F. Fisher. "Plutonium Oxidation Studies, " Chemical Engineering Division Research Highlights--May 1963April 1964, ANL-6875. Argonne National Laboratory

22. K. S. Covert and M. Kolodney. Protection of Plutonium Against Atmospheric Oxidation, LA-314. Los Alamos Scientific Laboratory. June 1945.

23 J. B. Raynor and J. F. Sackman. "Oxidation of Plutonium in Moist Air and Argon," Nature, vol. 197, pp. 587-588. February 1963.

24. J. G. Schnizlein and D. F. Fisher. "Plutonium Oxidation and Ignition Studies, "Chemical Engineering Division Summary Report, July-December 1963, ANL-6800. Argonne National Laboratory.

25. J. T. Waber, W. M. Olsen, and B. B. Roof, Jr. "Atmospheric Corrosion Test of Several Delta Phase Alloys of Plutonium," J. Nucl. Mater., vol. 3, p. 201.

26. R. F. Carter, B. Foy, and K. Stewart. The Particulate Material Formed by the Oxidation of Plutonium, A ERO-CONF/8.

27. J. G. Schnizlein and D. F. Fisher. "Plutonium Oxidation and Ignition Studies, "Chemical Engineering Division Summary Report, January-March 1962, ANL-6548. Argonne National Laboratory.

28. J. G. Schnizlein and D. F. Fisher. "Plutonium Ignition Studies," Chemical Engineering Division Summary Report, October-December 1962, ANL 6648. Argonne National Laboratory.

29. H. C. Barlow and J. F. Sackman. The Corrosion of $\delta$ Stabilized Plutonium in Sea Water, AWRE Report No. 0-11/63. Aldermaston, Berks, England. July 1963.

30. D. A. Frank-Kamenetskii. Diffusion and Heat Exchange in Chemical Kinetics (Translated by N. Thon), Princeton University Press, Princeton, New Jersey, 1955. 
31. R. K. Hilliard. Oxidation of Uranium in Air at High Temperatures, HW-58022. December 1958.

32. J. N. Wanklyn. The Ignition of Uranium, AERE-M/M 184. UKAEA, Research Group, AERE, Harwell, England. December 1957.

33. R. K. Hilliard. Characteristics of Burning Plutonium, HW-77531. April 1963.

34. O. N. Zanger, Ed。 Fire Incident 233-S Facility, Vol. I and III. (Official Use Only)

35. D. E. Guthrie and J. P. Nichols. Theoretical Possibilities and Consequences of Major Accidents in $\overline{\mathrm{U}}^{2} 35$ and $\mathrm{Pu}^{2} 39 \overline{\text { Fuel Fabrication }}$ and Radioisotope Processing Plants, ORNL-3441. Union Carbide Corporation, Oak Ridge, Tennessee.

36. L. C. Schwendiman, G. A. Sehmel, and A. K. Postma, Radioactive Particle Retention in Aerosol Transport Systems, HW-SA-3210. October 1963.

37. C. L. Cheevers. "Recent Air Cleaning Developments at Argonne National Laboratory, " in 7th Air Cleaning Conference at Brookhaven National Laboratory, TID-7627.

38. S. K. Friedlander and H. F. Johnstone. "Deposition of Suspended Particles from Turbulent Gas Streams, " Ind. and Eng. Chem., vol. 49, no. 7, pp. 1151-1156.

39. A. C. Chamberlain. Transport of Particles Across Boundary Layers, AERE-M-112. AERE, Harwell, England. November 1962.

40. H. G. Tanner. "Evanescence of Cloud Chamber Aerosols, "Arch. of New York Academy of Science, March 1963.

41. K. Stewart. The Resuspension of Particulate Material from Surfaces, paper presented at the International Symposium on Surface Contamination at Gatlinburg, Tennessee, June 1964.

42. H. Glauberman, W. R. Bootman, and R: J. Breslin. Studies of the Significance of Surface Contamination, paper presented at the International Symposium on Surface Contamination at Gatlinburg, Tennessee, June 1964.

43. The Hazards and Characteristics of Plutonium and Uranium Contamination, Np 10553. Nuclear Branch AWTG, Field Command, DASA, Sandia Base, Albuquerque, New Mexico. March 1961.

44. E. J. Leahy and A. L. Smith. Contamination Control Procedures for Special Weapons Accidents, USNRDL-TR/283. December 1958.

45. J. D. Shreve, Jr. Summary Report, Test Group 57, Operation Plumbob, ITB-1515 del.

46. I. S. Jones and S. F. Pond. Some Experiments to Determine the Resuspension Factor of Plutonium from Various Surfaces, AERE-R/ 4635. UKAEA, AERE, Harwell, England. 
47. R. T. Brunskill. The Relationship Between Surface and Airborne Contamination, paper presented to the International Symposium on Surface Contamination at Gatlinburg, Tennessee, June 1964.

48. M. Corn. Mechanisms of Dust Redispersion, paper presented to the International Symposium on Surface Contamination, Gatlinburg, Tennessee, June 1964. Graduate School of Public Health, University of Pittsburgh, Pennsylvania. 


\section{INTERNAL DISTRIBUTION}

\section{Copy Number}

\begin{tabular}{ll}
1 & A. E. Albrethsen \\
2 & G. J. Alkire/W. A. Haney \\
3 & B. V. Andersen \\
4 & G. E. Backman \\
5 & W. J. Bair \\
6 & J. J. Fuquay \\
7 & R. K. Hilliard \\
8 & E. R. Irish \\
9 & R. L. Junkins \\
10 & A. R. Keene \\
11 & H. A. Kornberg \\
12 & C. E. Linderoth \\
13 & J.D. McCormack \\
$14-38$ & J. Mishima \\
39 & A. K. Postma \\
40 & D. L. Reid \\
41 & L. C. Schwendiman \\
42 & G. A. Sehmel \\
43 & R. J. Sloat \\
44 & E. O. Swain \\
45 & R. E. Tomlinson \\
46 & M. T. Walling, Jr. \\
47 & E. C. Watson \\
48 & O. J. Wick \\
49 & 300 File \\
50 & Record Center \\
51 & HAPO Transfer and Accountability \\
52 & Technical Publications \\
$53-57$ & Extra \\
\hline &
\end{tabular}

\section{EXTERNAL DISTRIBUTION (Special)}

No. of Copies

1

2

2
Atomic Energy Commission, Washington Military Liaison Committee Attn: Captain D. E. McCoy, Staff Assistant to the Chairman

General Electric Technical Data Center, Schenectady

Richland Operations Office

Attn: R. K。 Sharp

Technical Information Library 
UC-41

HEALTH AND SAFETY

Ptd.

12

2

1

I

1

1

2

1

1

1
Standard Distribution

ABERDEEN PROVING GROUND

AEROJET.GENERAL CORPORATION

AEROJET-GENERAL NUCLEONICS

AERONAUTICAL SYSTEMS DIVISION

AIR FORCE INSTITUTE OF TECHNOLOGY

AIR FORCE SURGEON GENERAL

AIR FORCE SYSTEMS COMMAND

AIR FORCE WEAPONS LABORATORY

ALBUQUERQUE OPERATIONS OFFICE

ALLIS-CHALMERS MANUFACTURING COMPANY

ALLIS-CHALMERS MANUFACTURING COMPANY, BETHESDA

ALLISON DIVISION-GMC

ARGONNE CANCER RESEARCH HOSPITAL

ARGONNE NATIONAL LABORATORY

ARMED FORCES RADIOBIOLOGY RESEARCH INSTITUTE

ARMY CHEMICAL RESEARCH AND DEVELOPMENT LABORATORIES

ARMY ELECTRONICS RESEARCH AND DEVELOPMENT LABORATORIES

ARMY ENVIRONMENTAL HYGIENE AGENCY

ARMY MATERIALS RESEARCH AGENCY

ARMY MEDICAL RESEARCH LABORATORY

ARMY NATICK LABORATORIES

ARMY NUCLEAR DEFENSE LABORATORY

ARMY SURGEON GENERAL

ARMY TANK-AUTOMOTIVE CENTER

ATOMIC BOMB CASUALTY COMMISSION

ATOMIC ENERGY COMMISSION, BETHESDA

AEC SCIENTIFIC REPRESENTATIVE, ARGENTINA

AEC SCIENTIFIC RE PRESENTATIVE, BELGIUM

AEC SCIENTIFIC REPRESENTATIVE, FRANCE

AEC SCIENTIFIC REPRESENTATIVE, JAPAN

ATOMIC ENERGY COMMISSION, WASHINGTON

ATOMIC ENERGY OF CANADA LIMITED

Ptd.

2

I

2

4

l

I

1

1

1

1

1

1

1

1

1

1

1

3

1

1

1

1

1

1

2

2

ATOMIC ENERGY OF CANADA LIMITED, WHITESHELL
TID -4500

37th Ed.

Standard Distribution

ATOMICS INTERNATIONAL

BABCOCK AND WILCOX COMPANY

BATTELLE MEMORIAL INSTITUTE

BERYLLIUM CORPORATION

BROOKE ARMY MEDICAL CENTER

BROOKHAYEN NATIONAL LABORATORY

BUREAU OF MINES, ALBANY

BUREAU OF MINES. BARTLESVILLE

BUREAU OF MINES, SALT LAKE CITY

BUREAU OF MINES. WASHINGTON

BUREAU OF SHIPS (CODE 1500)

BUREAU OF YARDS AND DOCKS

CHICAGO PATENT GROUP

COAST GUARD

COLUMBIA UNIVERSITY (ROSSI)

COMBUSTION ENGINEERING, INC.

COMBUSTION ENGINEERING, INC. (NRD)

COMMITTEE ON THE EFFECTS OF ATOMIC RADIATION

DEFENCE RESEARCH MEMBER

DEFENSE ATOMIC SUPPORT AGENCY, WASHINGTON

*DEL ELECTRONICS CORPORATION DIVISION OF RAW MATERIALS, WASHINGTON DOW CHEMICAL COMPANY, ROCKY FLATS

DU PONT COMPANY, AIKEN

DU PONT COMPANY, WILMINGTON

EDGERTON, GERMESHAUSEN AND GRIER, INC., GOLETA

EDGERTON, GERMESHAUSEN AND GRIER, INC., LAS VEGAS

EDGEWOOD ARSENAL

FRANKFORD ARSENAL

FUNDAMENTAL METHODS ASSOCIATION

GENERAL ATOMIC DIVISION

GENERAL DYNAMICS/FORT WORTH

GENERAL ELECTRIC COMPANY, CINCINNATI

general eleCtric COMPANy. PLEASANTON

GENERAL ELECTRIC COMPANY, SAN JOSE

GENERAL INSTRUMENT CORPORATION 


Ptd.
1
1
1
1
1
1
2
1
1
1
2
1
1
1
1
1
1
1
1
1
1
1

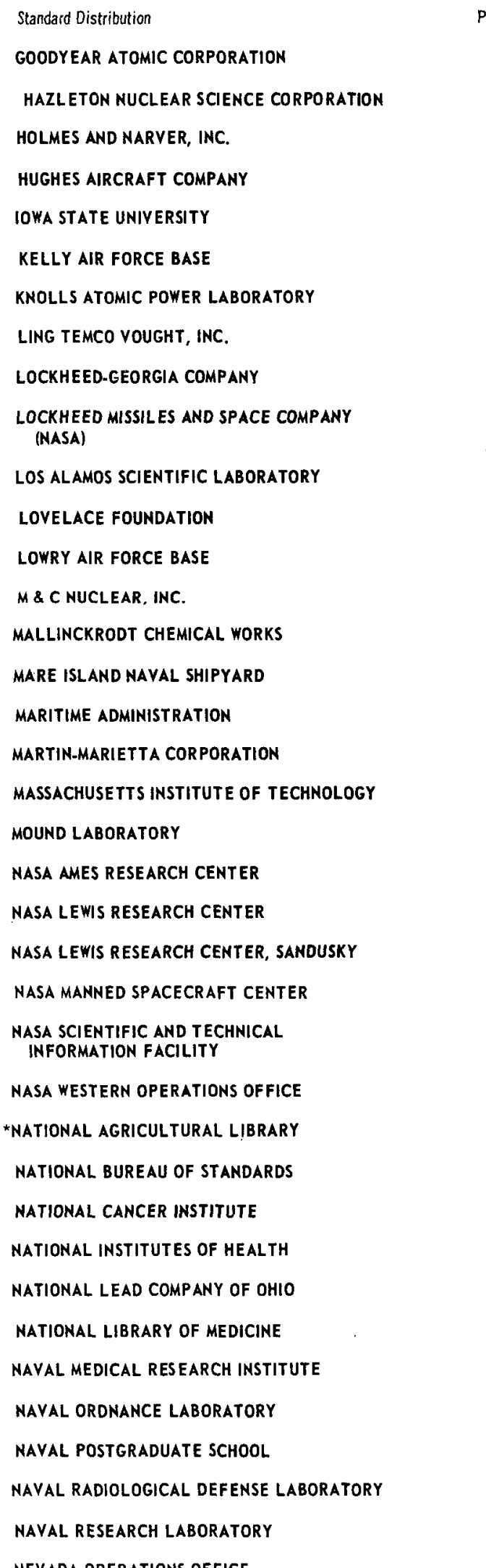

Pto.

Standard Distribution

NEW BRUNSWICK AREA OFFICE

NEW JERSEY STATE DEPARTMENT OF HEALTH NEW YORK OPERATIONS OFFICE NEW YORK UNIVERSITY (EISENBUD) NRA. INC. 
UC-41

HEAL TH AND SAFETY

Ptd.

1

1

1

1

1

1

1

1

1

2
Standard Distribution

SCHENECTADY NAVAL REACTORS OFFICE

SCHOOL OF AEROSPACE MEDICINE

SECOND AIR FORCE (SAC)

SOUTHWEST RESEARCH INSTITUTE

STANFORD UNIVERSITY (SLAC)

STRATEGIC AIR COMMAND

SYLYANIA ELECTRIC PRODUCTS, INC.

TENNESSEE VALLEY AUTHORITY

TODD SHIPYARDS CORPORATION

TRW SPACE TECHNOLOGY LABORATORIES (NASA)

TULANE UNIVERSITY

UNION CARBIDE CORPORATION (ORGDP)

UNION CARBIDE CORPORATION (ORNL)

UNITED NUCLEAR CORPORATION (NDA)

U. S. GEOLOGICAL SURVEY (BAL)

U. S. GEOLOGICAL SURVEY, DENYER

U. S. GEOLOGICAL SURVEY, MENLO PARK

U. S. GEOLOGICAL SURVEY, WASHINGTON

U. S. WEATHER BUREAU, LAS VEGAS

U. S. WEATHER BUREAU, WASHINGTON
Ptd.

4

1

2

1

1

1

1

I
Standard Distribution

UNIVERSITY OF CALIFORNIA, BERKELEY

UNIVERSITY OF CALIFORNIA. DAVIS

UNIVERSITY OF CALIFORNIA, LIVERMORE

UNIVERSITY OF CALIFORNIA, LOS ANGELES

UNIVERSITY OF CALIFORNIA, SAN FRANCISCO

UNIVERSITY OF CHICAGO, USAF RADIATION LABORATORY

UNIVERSITY OF HAWAII

UNIVERSITY OF PUERTO RICO

UNIVERSITY OF ROCHESTER

UNIVERSITY OF TENMESSEE (UTA)

UNIVERSITY OF UTAH

UNIVERSITY OF WASHINGTON

WALTER REED ARMY MEDICAL CENTER

WAYNE STATE UNIVERSITY

WESTERN RESERVE UNIVERSITY

WESTINGHOUSE BETTIS ATOMIC POWER LABORATORY

WESTIMGHOUSE ELECTRIC CORPORATION

WESTINGHOUSE ELECTRIC CORPORATION (NASA)

WHITE SANDS MISSILE RANGE

DIVISION OF TECHNICAL INFORMATION EXTENSION

CLEARINGHOUSE FOR FEDERAL SCIENTIFIC AND TECHNICAL INFORMATION. 